J. AMER. Soc. HorT. SCI. 115(3):405-411. 1990.

\title{
'Stayman' Fruit Cracking as Affected by Surfactants, Plant Growth Regulators, and Other Chemicals
}

\author{
R.E. Byers ${ }^{1}$, D.H. Carbaugh ${ }^{2}$, and C.N. Presley ${ }^{3}$ \\ Department of Horticulture, Winchester-Agricultural Experiment Station, Virginia Polytechnic \\ Institute and State University, 2500 Valley Avenue, Winchester, VA 22601 \\ Additional index words. gibberellin, daminozide, pesticides
}

\begin{abstract}
Submerging 'Stayman' apples in nonionic and anionic surfactant-water solutions caused increased water uptake and fruit cracking. The primary sites of water uptake were lenticels and injured areas of the fruit cuticle. Fruit cracking caused by submerging fruit in $1.25 \mathrm{ml}$ X-77/liter surfactant was used to predict the natural cracking potential of 'Stayman' strains and apple cultivars in the field. Submerging apples in aqueous pesticide mixtures did not Increase fruit cracking or water uptake. Fruit cracking and uptake of surfactant-water were not correlated between apple cultivars. In a surfactant-water bath, 'Starkrimson Delicious' absorbed more water than 'Stayman', 'York', 'Jonathan', and 'Golden Delicious'; no 'Starkrimson Delicious' fruits cracked, but 32\% to 80\% of the other cultivars did. In field tests, four airblast spray applications of $\mathbf{G A}_{4+7}$ in July and Aug. 1987 reduced fruit cracking from 56\% to $21 \%$, and five applications In July, Aug., and Sept. 1988 reduced fruit cracking from $93 \%$ to $75 \%$. In 1987, daminozide reduced cracking, but, in 1988, neither daminozide, NAA, nor Vapor Gard alone reduced cracking. However, in 1988, a combination treatment of $\mathbf{G A}_{4+7}$, daminozide, NAA, and Vapor Gard reduced fruit cracking from $93 \%$ to $22 \%$. Also, two scorings of the trunk with a carpet knife reduced fruit cracking $22 \%$. Chemical names used: alkylaryl polyoxyethylene alcohol glycol (X-77); butanedioic acid mono(2,2-dimethylhydrazide) (daminozide); naphthaleneacetic acid (NAA); di-1-p-methene (Vapor Gard); gibberellic acid $\left(\mathbf{G A}_{4+7}\right)$.
\end{abstract}

In cherry, apple, grape, nectarine, plum, tomato, citrus, and many other fruits, cracking of the skin and fleshy tissues before harvest results in great economic loss to growers. Rapid deterioration of the fruit usually follows exposure of the ruptured tissue to air.

'Stayman' fruit cracking usually occurs only during relatively long rainy periods after fruit have attained $5 \mathrm{~cm}$ or more in diameter. Fruits borne on the outer periphery of the tree and exposed to the sun, russeted fruit, highly colored fruit, or the sides of the fruits with the greater sugar concentrations are more susceptible to cracking (Verner, 1935). Dry periods followed by rain are commonly thought to cause a great or sudden increase in water content of the fruit, thus causing fruit to crack. However, Verner (1935) induced drought conditions by covering the soil with tarpaulins for 37 days, then flooding the soil with $10 \mathrm{~cm}$ of water. Within $10 \mathrm{hr}$, the percentage soil moisture increased from $12 \%$ to $20 \%$, but this change failed to induce cracking. During the 37 days when the soil was covered, fruit on these trees cracked similarly to those on trees with no tarpaulins. Verner (1935) believed that fruit cracked in rain or high humidity periods only when the relative humidity was near $100 \%$ for $6 \mathrm{hr}$ or more. Covering limbs with a tarpaulin during a rain period did not protect the fruit from cracking (Verner, 1935). Further research seemed to be needed to determine if prolonged

Received for publication 3 May 1989. Appreciation is extended to Sharon Myers and R.H. Myers, Dept. of Statistics. Virginia Polytechnic Inst. and State Univ., Blacksburg, for assistance in the analysis of data; Abbott Laboratories (gibberellin), Miller Chemical Co. (Vapor Gard), and Uniroyal (daminozide) for chemical supplies: and to the Virginia State Horticultural Society and Abbott Laboratories for partial financial assistance. The cost of publishing this paper was defrayed in part by the payment of page charges. Under postal regulations, this paper therefore must be hereby marked advertisement solely to indicate this fact.

${ }^{1}$ Professor of Horticulture.

${ }^{2}$ Agricultural Manager.

${ }^{3}$ Agricultural Technician. skin wetting increased cracking of 'Stayman' fruit and the involvement of leaves in water absorption.

In sweet cherry, fruit cracking was thought to be caused primarily by absorption of water through the fruit cuticle (Davenport et al., 1972). Verner (1935) found that some 'Stayman' fruit would crack if submerged in water for 1 to 3 days whether attached to the tree or not. In sweet cherries, Anderson and Richardson (1975) found that fruit cracking was not strictly related to soluble solids concentration, osmotic potential, turgor, or fruit water potential. These results suggest that the degree of cuticular permeability, cuticular strength, or cell wall strength may be more important than water potential characteristics.

Various growth regulators and nutrient sprays have reduced cracking of 'Stayman' apple-daminozide (Costa et al., 1983; Sullivan and Widmoyer, 1970); sweet cherry-NAA (Bullock, 1952), calcium ions (Callan, 1986), antitranspirants (Davenport et al., 1972), ethyl oleate (Harrington et al., 1978); and tomato-IAA, GA 3 , NAA (Batal et al., 1972). Yoda and Ashida (1960) reported that the growth effect of auxins increased the plasticity and, to some extent, reduced elasticity of pea stems, and gibberellin acted in an opposite way. Adams et al. (1975), however, found that gibberellin greatly increased plasticity in Avena stems.

In grapes, spray adjuvants have been shown to increase water uptake and fruit cracking in the laboratory (Marois et al., 1987). Fungicides and insecticides are frequently formulated with surfactants to improve uniform coating of the fruit and leaves. Surfactants are known to decrease the surface tension of water, thus preventing the beading of spray materials on waxy surfaces. Surfactants are also known to increase the penetration of water, spray chemicals, and nutrients through apple cuticles (Westwood and Batjer, 1960).

The objectives of these experiments were to: 1) develop a laboratory technique for determining differences in susceptibility of 'Stayman' fruits to cracking, 2) evaluate the influence of various surfactants on fruit cracking, 3) determine if pesticide 
formulations would increase water uptake and crack the fruit, 4) determine the primary location of water uptake by fruit submerged in surfactant solutions, 5) evaluate potential chemical protectants (water repellents) in a surfactant-water bath test, 6) evaluate spray treatments for decreasing or increasing fruit cracking, 7) determine if root pruning, summer or winter branch pruning, or scoring the tree trunk would alter fruit cracking in the field, and 8) determine if bagging individual fruit would prevent fruit cracking when trees were watered from above.

\section{Materials and Methods}

A description of chemicals used in the following experiments is given in Table 1.

Experiment 1. 'Stayman' apples harvested on 21 Sept. 1987 from 10-year-old 'Stayman'/seedling trees ('201 Stayman' strain) were randomized and 25 fruits for each treatment were numbered on the skin with a marker, individually weighed on a toploading balance ( $\pm 1 \mathrm{mg}$ ), and submerged in buckets of water or aqueous solutions of X-77 (nonionic surfactant) from 1.25 to
$0.036 \mathrm{ml} \cdot$ liter $^{-1}$. After 1 and 3 days of submersion, each individual apple was blotted dry with paper towels and examined for fruit cracks, and each one was reweighed after 3 days. The percentage weight gain was determined separately for noncracked and cracked apples.

Experiment 2. Noncracked 'Stayman' apples were harvested in mid-Oct. 1987 from a block of apples that had a high percentage of cracked fruit. Fruit were randomized into eight buckets containing 25 fruits each (two replicate buckets/treatment). Each fruit was marked, individually weighed, and submerged in: 1) water, 2) $1.25 \mathrm{ml} \mathrm{X-77/liter} \mathrm{(nonionic} \mathrm{surfactant),} \mathrm{3)} 1.25$ $\mathrm{ml}$ Downey water softener/liter (cationic), and 4) $1.25 \mathrm{ml} \mathrm{GR}$ Miter (anionic surfactant). After 3 days of submersion, 25 apples from one bucket were blotted dry with paper towels, reweighed, and examined for cracks. The percentage weight gain was determined for noncracked and cracked apples. In addition, 25 apples were placed in either X-77 surfactant solution at 1.25 ml-liter ${ }^{-1}$ or in water; $0.5 \mathrm{~g}$ methylene blue dye/liter was added to each bucket. Five apples from each bucket were peeled after

Table 1. Names of chemicals used.

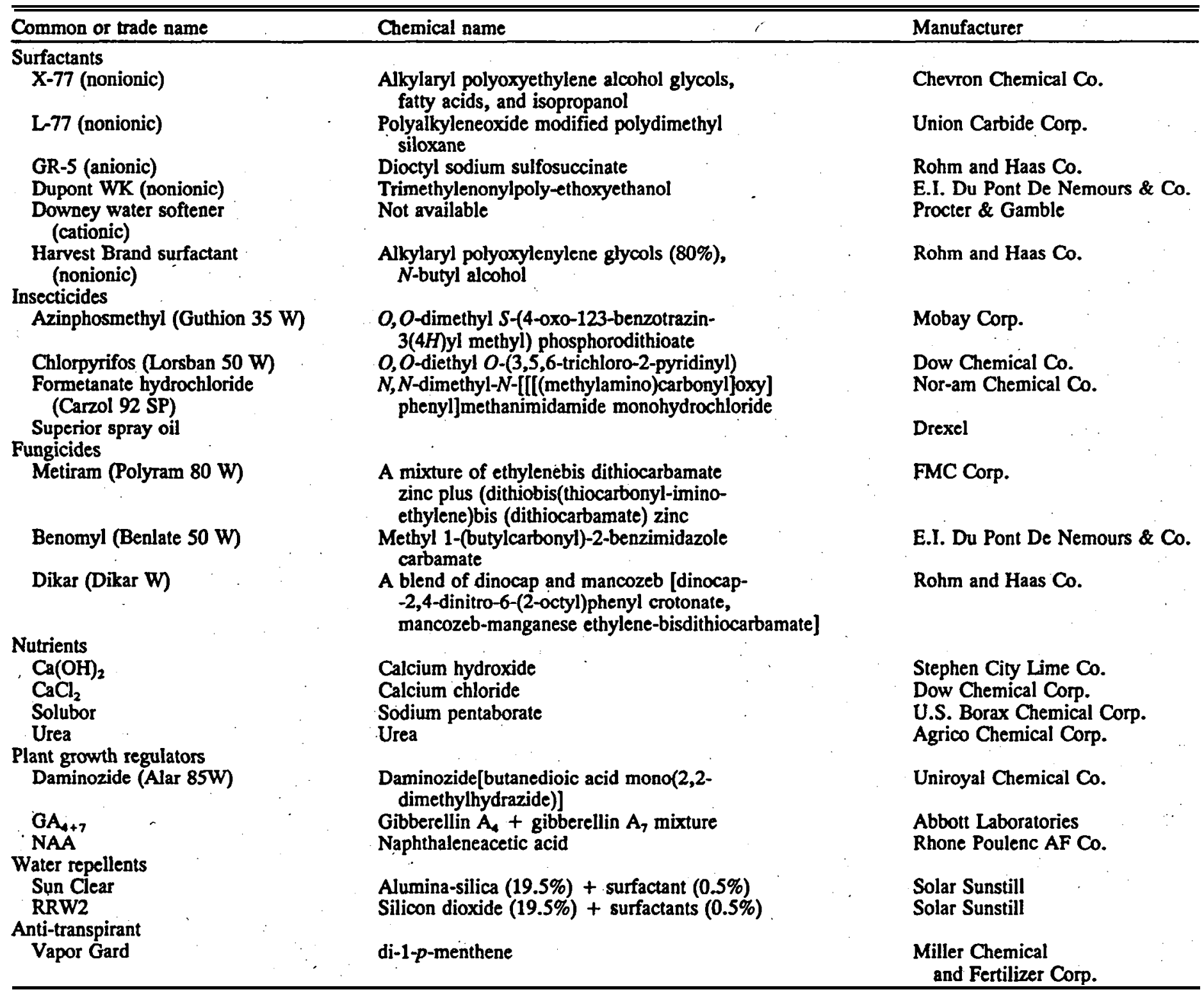


1 or 3 days to determine the possible sites of water entry into the fruit.

Experiment 3. 'Stayman' apples harvested 5 Oct. 1988 were randomized into 16 buckets containing 20 apples each. Two buckets of apples were randomly assigned to each of eight treatments (see Table 4 for a complete list of chemicals and rates used). Each fruit was examined for cracks after 3 or 7 days of submersion.

Experiment 4. 'Stayman' apples harvested in mid-Oct. 1987 were stored at 0C in regular cold storage until Feb. 1988. Fruit were randomized into 15 buckets containing 25 fruit each. Each fruit was marked and individually weighed and submerged in various surfactant or pesticide mixtures 2-7 Feb. 1987 (see Table 5 for a listing of treatments). Treatments 8-11 and 13-15 were treated, air dried, and then submerged in $1.25 \mathrm{ml} \mathrm{X-77/}$ liter.

Experiment 5. Twenty-five fruit from each of several cultivars harvested 22 Sept. 1987 were submerged in buckets with 1.25 $\mathrm{ml} \mathrm{X-77/liter.} \mathrm{Each} \mathrm{fruit} \mathrm{was} \mathrm{numbered} \mathrm{on} \mathrm{the} \mathrm{skin} \mathrm{with} \mathrm{a} \mathrm{marker}$ and individually weighed. After 1 or 3 days of submersion, each apple was blotted dry with a paper towel and examined for cracks and reweighed after 3 days, when the percentage weight gain was determined for noncracked and cracked apples.

Experiment 6. 'Stayman' fruit were randomly collected at a height of 1 to $2 \mathrm{~m}$ from the periphery of trees sprayed with daminozide and $\mathrm{GA}_{4+7}$, weighed, and submerged in buckets of $\mathrm{X}-77$ at $1.25 \mathrm{ml} \cdot \mathrm{liter}^{-1}$. After 1 or 3 days of submersion, each individual apple was blotted dry with a paper towel and examined for cracks and reweighed at 3 days. The percentage weight gain was determined for noncracked and cracked apples.

Experiment 7. In 1987, 30 12-year-old 'Stayman'/seedling trees were selected for uniform crop load and grouped into six blocks according to terrain. Alternate trees within a single row were used to avoid drift when individual trees were sprayed with an airblast sprayer calibrated for 2805 liters $\cdot \mathrm{ha}^{-1}$ [300 gal/ acre dilute that was calculated by the Tree-Row-Volume (TRV) method (Byers, 1987)]. Treatments were as follows: 1) control-no treatment; 2) $20 \mathrm{mg} \mathrm{GA} \mathrm{GA}_{4} / \mathrm{liter}$ on 5, 13, 21, and 29 May; 3) $20 \mathrm{mg} \mathrm{GA} 4+7 /$ iter on 24 July, 3, 11, and 17 Aug.; 4) same as treatment 3 plus $9.6 \mathrm{~g} \mathrm{Ca}(\mathrm{OH})_{2} /$ liter tank-mixed in each spray; and 5) $1000 \mathrm{mg}$ daminozide/liter on $27 \mathrm{July}$.
Four limbs carrying a total of 30 to 60 fruit were tagged per tree. Weekly, from 24 July to 1.5 Oct., the cracked fruit on the tagged limbs were counted, removed, and the percentage fruit cracked was calculated for each date. Trees were evaluated for return bloom in 1988 using a rating scale from 0 to 10 . A rating of 4 would be adequate bloom for a full crop.

Experiment 8. In 1988, 78 15-year-old 'Stayman'/seedling trees were selected for uniform crop load and grouped into six blocks according to terrain. Alternate trees within rows and two border rows between treatment rows were used to avoid drift when individual trees were sprayed with an airblast sprayer. Applications were made 7 and 21 July, 14 and 18 Aug., and 9 Sept. (except that daminozide was applied only on 7 July) with a Swanson three-point hitch airblast sprayer calibrated at 2337 liters $\cdot \mathrm{ha}^{-1}$ [250 gal/acre dilute (TRV)]. Treatments were as follows: 1) control-no treatment, 2) $10 \mathrm{mg} \mathrm{GA} 4+7 /$ liter, 3) $2 \mathrm{mg}$ $\mathrm{GA}_{4+7} /$ liter, 4) $2 \mathrm{mg} \mathrm{GA}+4 /$ liter $+2.5 \mathrm{ml}$ superior oil/liter, 5) $10 \mathrm{mg} \mathrm{GA}+7 /$ liter $+1000 \mathrm{mg}$ daminozide/liter, 6) $1000 \mathrm{mg}$ daminozide/liter, 7) $2.5 \mathrm{ml}$ superior oil/liter, 8) $5.0 \mathrm{ml}$ Vapor Gard/liter, 9) $20 \mathrm{mg}$ NAA/liter, 10) $20 \mathrm{mg} \mathrm{NAA} / \mathrm{liter}+10 \mathrm{mg}$ $\mathrm{GA}_{4+7} /$ liter + $1000 \mathrm{mg}$ daminozide/liter + $5.0 \mathrm{ml}$ Vapor Gard/ liter, 11) $1.25 \mathrm{ml} \mathrm{X-77/liter,} \mathrm{12)} 10 \mathrm{ml}$ Sun Clear/liter, and 13) $10 \mathrm{ml} \mathrm{RRW} 2 /$ liter. Four limbs were selected on each tree having a total of 50 to 65 fruit per tree. Weekly, from 7 July to 11 Oct., the cracked fruit on the tagged limbs were counted, removed, and the percentage cracked fruit was calculated. Ten fruit from each tree were rated for percent of fruit showing some red surface on 28 Sept. 1988.

Experiment 9. In 1988, 45 15-year-old 'Stayman'/seedling trees were selected for uniform size and form and grouped into nine blocks according to terrain. Five cultural treatments were randomized in each block as follows: 1) control-light dormant pruning in Feb. 1988, 2) no pruning, 3) root pruned with a subsoiler on both sides of the tree $\approx 1.5 \mathrm{~m}$ from the trunk and $\approx 1.5 \mathrm{~m}$ in depth on 3 June, 4) two scores to the trunk with a carpet knife on 12 July, 5) all terminal growth longer than $0.3 \mathrm{~m}$ removed on $12 \mathrm{July.} \mathrm{Four} \mathrm{limbs} \mathrm{were} \mathrm{se-}$ lected on each tree having a total of 50 to 65 fruit per tree. Weekly, from 7 July to 11 Oct., the number of cracked fruit on the tagged limbs were counted and removed and the percentage cracked fruit was calculated for each date. Ten fruit

Table 2. Effect of submerging 'Stayman' apples in water or surfactant (X-77) water solutions on fruit cracking and percentage weight gain (21-24 Sept. 1987, Expt. 1).

\begin{tabular}{|c|c|c|c|c|c|}
\hline \multirow{3}{*}{$\begin{array}{l}\text { Surfactant } \\
\text { concn } \\
\left(\mathrm{ml} \cdot \text { liter }^{-1}\right)\end{array}$} & \multirow{2}{*}{\multicolumn{2}{|c|}{$\begin{array}{c}\text { Fruit } \\
\text { cracked }(\%)^{x}\end{array}$}} & \multicolumn{3}{|c|}{ Mean weight gain after 3 days $(\%)^{y}$} \\
\hline & & & \multirow{2}{*}{$\begin{array}{l}\text { Noncracked } \\
\text { apples }\end{array}$} & \multirow{2}{*}{$\begin{array}{l}\text { Cracked } \\
\text { apples }\end{array}$} & \multirow{2}{*}{$\begin{array}{c}\text { All } \\
\text { apples }\end{array}$} \\
\hline & Day 1 & Day 3 & & & \\
\hline 0 & 4 & 16 & $0.46 \pm 0.08$ & $0.91 \pm 0.75$ & $0.53 \pm 0.12$ \\
\hline 0.036 & 8 & 28 & $0.81 \pm 0.10$ & $1.39 \pm 0.45$ & $0.95 \pm 0.15$ \\
\hline 0.078 & 12 & 28 & $0.94 \pm 0.13$ & $1.37 \pm 0.31$ & $1.06 \pm 0.14$ \\
\hline 0.16 & $32 *$ & 40 & $1.13 \pm 0.27$ & $2.48 \pm 0.99$ & $1.67 \pm 0.47$ \\
\hline 0.31 & $28^{*}$ & 36 & $1.39 \pm 0.24$ & $1.84 \pm 0.76$ & $1.55 \pm 0.29$ \\
\hline 0.65 & $28 *$ & $64^{*}$ & $2.20 \pm 0.78$ & $2.27 \pm 0.40$ & $2.24 \pm 0.36$ \\
\hline 1.25 & $32^{*}$ & $52^{*}$ & $1.86 \pm 0.41$ & $2.26 \pm 0.38$ & $2.07 \pm 0.27$ \\
\hline Significance $x$ & & $\mathrm{~L}^{* * \mathrm{Q}^{*} *}$ & $\mathrm{~L}^{* *} \mathrm{Q}^{* *}$ & $\mathrm{~L}^{* *} \mathrm{Q}^{* *}$ & $\mathrm{~L}^{* *} \mathrm{Q}^{* *}$ \\
\hline
\end{tabular}

${ }^{\mathrm{z}}$ Chi-square comparison of each treatment with the control, $P=0.05(*)$. Means of one 25-apple replicate per treatment.

${ }^{\mathrm{y}}$ Confidence limits, $P=0.05(*)$ for cracked, noncracked, and all apples in each 25 apple group.

${ }^{\mathrm{x}}$ Significance: linear $(\mathrm{L})$ and quadratic $(\mathrm{Q}) ; P=0.05(*)$ or $0.01(* *)$. For percent fruit cracked, $\mathrm{n}=1$ replicate of 25 fruit; for percent weight gain, $\mathrm{n}=25$ fruit or the portion thereof cracked or noncracked.

J. Amer. Soc. Hort. Sci. 115(3):405-411. 1990. 
from each tree were rated for percent of fruit showing some red surface on 17 Oct. 1988.

Experiment 10. In 1988, 15-year-old 'Stayman'/seedling trees were selected for uniform crop load and grouped into eight blocks according to terrain. The following treatments were randomized within each block: 1) control-no treatment, 2) undertree sprinkling for $12 \mathrm{hr}$ for each of six consecutive nights (3 to 9 Aug.) with $5 \mathrm{~cm}$ of water per night, 3) overhead sprinkling for $12 \mathrm{hr}$ for each of six nights (3 to 9 Aug.) with $5 \mathrm{~cm}$ of water per night. Buffer trees were used between treatments to prevent cross-treatment influence. Twenty-five fruit were tagged on each tree and observed 1 and 6 days after treatment. In addition, on trees that were sprinkled overhead, 25 fruit were bagged with paper bags and 25 fruit were coated with a thin layer of petroleum jelly on 3 Aug.

Statistical analyses were performed using SAS General Linear Model procedures. When differences were significant, least significance difference and Duncan's multiple range tests were used for mean separation. Chi-square tests were used to compare means of laboratory submersion tests when only one 20- to 40apple sample was used. The mean and 95\% confidence limits for the percent weight gain of submerged apples were calculated for each treatment and, where appropriate, were further analyzed using regression analysis. The percent weight gain for cracked and noncracked apples for each 25-apple sample had unequal numbers, since the number of noncracked and cracked fruit per treatment changed.

\section{Results and Discussion}

Experiments 1 and 2. Water uptake and fruit cracking within $24 \mathrm{hr}$ increased linearly with increasing concentration of X-77 (Table 2). A nonionic (X-77) and an anionic (GR5) surfactant caused increased fruit cracking and water uptake, but the cationic surfactant (Downey) did not (Table 3). Apples submerged in methylene blue dye (with or without surfactant) and peeled indicated that the primary uptake of water was through lenticels and injured areas of the fruit cuticle. Some sides of the fruit showed no dye penetrating into the apple flesh and other sides showed blue spots in proportion to the lenticel size or injury ( d a t a not s how n ).

Experiment 3. Submerging 'Stayman' apples in pesticide combinations or nutrient solutions generally did not affect fruit cracking (Table 4). However, the daminozide + surfactant combination increased fruit cracking. We presume the surfactant was the constituent primarily responsible for fruit cracking.

Experiment 4. 'Stayman' apples held in cold storage for 3.5 months and then submerged in water or surfactants (Table 5)

Table 3. Effect of submerging 'Stayman' apples in water or a surfactant solution at $1.25 \mathrm{ml} \cdot$ liter $^{-1}$ on fruit cracking (26-29 Nov. 1987, Expt. 2).

\begin{tabular}{lcc}
\hline \hline Surfactant & $\begin{array}{c}\text { Fruit } \\
\text { cracked on } \\
\text { day 3 (\%) }\end{array}$ & $\begin{array}{c}\text { Weight gain } \\
\text { after } 3 \text { days (\%) } \\
\text { (noncracked apples) }\end{array}$ \\
\hline None (water) & $20 \mathrm{a}$ & $0.29 \pm 0.075$ \\
X-77 (nonionic) & $\begin{array}{l}48 \mathrm{bc} \\
27 \mathrm{ab}\end{array}$ & $1.11 \pm 0.138$ \\
Downey (cationic) & $55 \mathrm{c}$ & $0.36 \pm 0.077$ \\
GR5 (anionic) & $1.53 \pm 0.252$ \\
\hline
\end{tabular}

"Mean separation within columns by Duncan's multiple range test, $P$ $=0.05$. Mean of two 25-apple replicates submerged for each treatment.

yConfidence limits, $P=0.05$ for noncracked in one 25-apple replicate per treament. cracked less and took up less water than those treated immediately after harvest (Tables 2 and 3). The surfactant DuPont WK caused more water uptake, expressed as weight gain, than X-77 or L-77 (Table 5). Pretreatment of fruit with Vapor Gard

Table 4. Effect of submerging 'Stayman' apples in various spray mixtures on fruit cracking (5-12 Oct. 1987, Expt. 3).

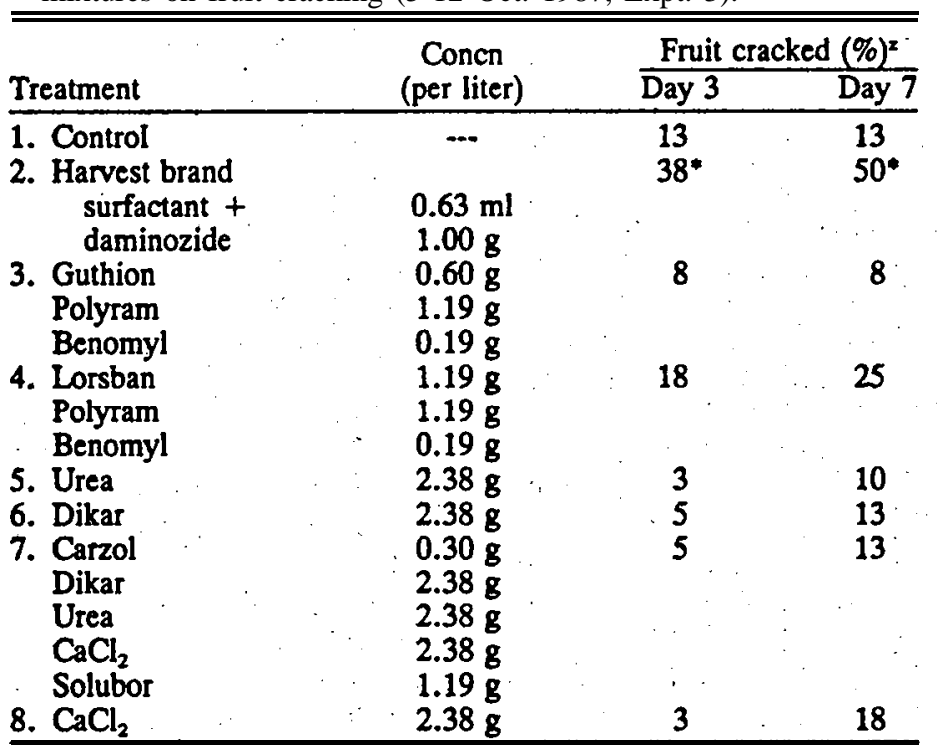

${ }^{\mathrm{z}}$ Each treatment within columns was compared to the. control by $\mathrm{x}^{2}, P$ $=0.05$. Differences indicated by (*). Means consisted of one 40-apple sample per treatment.

Table 5. Effect of submerging 'Stayman' apples after refrigerated storage in various chemical mixtures on fruit cracking (2-7 Feb. 1988, Expt. 4).

\begin{tabular}{|c|c|c|c|c|}
\hline \multirow[b]{2}{*}{ Chemical } & \multirow{2}{*}{$\begin{array}{c}\text { Concn } \\
\text { (per liter) }\end{array}$} & \multicolumn{2}{|c|}{$\begin{array}{c}\text { Fruit } \\
\text { cracked }(\%)^{y}\end{array}$} & \multirow{2}{*}{$\begin{array}{l}\text { Weight gain after } \\
2 \text { days }(\%)^{x}\end{array}$} \\
\hline & & Day 2 & Day 5 & \\
\hline 1. Water (control) & & 0 & 4 & $0.19 \pm 0.03$ \\
\hline 2. $x-77$ & $1.25 \mathrm{ml}$ & 8 & 8 & $0.65 \pm 0.07$ \\
\hline 3. $\mathrm{L}-77$ & $1.25 \mathrm{ml}$ & 8 & 12 & $0.69 \pm 0.09$ \\
\hline 4. WK & $1.25 \mathrm{ml}$ & 0 & 20 & $0.92 \pm 0.08$ \\
\hline 5. Guthion & $0.60 \mathrm{~g}$ & 0 & 4 & $0.22 \pm 0.03$ \\
\hline $\begin{array}{l}\text { Benomyl } \\
\text { Polyram }\end{array}$ & $\begin{array}{l}0.19 \mathrm{~g} \\
1.19 \mathrm{~g}\end{array}$ & & & \\
\hline 6. Lorsban & $1.19 \mathrm{~g}$ & $\mathbf{0}$ & 4 & $0.25 \pm 0.06$ \\
\hline $\begin{array}{l}\text { Benomyl } \\
\text { Polyram }\end{array}$ & $\begin{array}{l}0.19 \mathrm{~g} \\
1.19 \mathrm{~g}\end{array}$ & & & \\
\hline $\begin{array}{l}\text { 7. Carzol } \\
\text { Dikar }\end{array}$ & $\begin{array}{l}0.30 \mathrm{~g} \\
2.39 \mathrm{~g}\end{array}$ & 4 & 16 & $0.23 \pm 0.04$ \\
\hline 8. Vapor Gard ${ }^{z}$ & $10.00 \mathrm{ml}$ & 4. & $24^{*}$ & $0.63 \pm 0.09$ \\
\hline 9. Vapor Gardz & $40.00 \mathrm{ml}$ & 4 & 16 & $0.64 \pm 0.17$ \\
\hline 10. Peach wax & $40.00 \mathrm{ml}$ & $16^{*}$ & $28 * *$ & $0.73 \pm 0.08$ \\
\hline 11. $X-145 A$ wax ${ }^{2}$ & $40.00 \mathrm{ml}$ & 0 & 4 & $0.42 \pm 0.12$ \\
\hline 12. Sucrose $+X-77$ & $\begin{array}{l}68.4 \mathrm{~g} \\
1.25 \mathrm{ml}\end{array}$ & 0 & 16 & $0.65 \pm 0.02$ \\
\hline 13. Acetone & wash $3 \mathrm{sec}$ & 4 & $24^{*}$ & $1.14 \pm 0.12$ \\
\hline 14. Xylenez & wash $3 \mathrm{sec}$ & $\mathbf{0}$ & 8 & $1.03 \pm 0.10$ \\
\hline 15. Chloroform ${ }^{x}$ & wash $3 \mathrm{sec}$ & 0 & 8 & $1.77 \pm 0.17$ \\
\hline
\end{tabular}

${ }^{\mathrm{z}}$ After treatment, fruits were air dried,. then submerged in $1.25 \mathrm{ml}$ X-77/liter.

${ }^{\mathrm{y}}$ Each treatment was compared to the control by $\mathrm{x}^{2}, P=0.05$. Differences indicated by $(*)$. Each treatment consisted of a 40 -fruit sample.

${ }^{\mathrm{x}}$ Confidence limits, $P=0.05$, for noncracked apples in each treatment. 
Table 6. Effect of submersion of several apple cultivars in a surfactant solution $(0.125 \% \mathrm{X}-77)$ for 1 or 3 days on fruit cracking and percentage weight gain (2225 Sept. 1987, Expt. 5).

\begin{tabular}{|c|c|c|c|c|c|}
\hline \multirow[b]{3}{*}{ Cultivar } & \multirow{2}{*}{\multicolumn{2}{|c|}{$\begin{array}{c}\text { Fruit } \\
\text { cracked }(\%)^{z}\end{array}$}} & \multicolumn{3}{|c|}{ Mean weight gain after 3 days $(\%)^{y}$} \\
\hline & & & \multirow{2}{*}{$\begin{array}{l}\text { Noncracked } \\
\text { apples }\end{array}$} & \multirow{2}{*}{$\begin{array}{l}\text { Cracked } \\
\text { apples }\end{array}$} & \multirow{2}{*}{$\begin{array}{c}\text { All } \\
\text { apples }\end{array}$} \\
\hline & Day 1' & Day 3 & & & \\
\hline Stayman & 32 & 52 & $1.86 \pm 0.41$ & $2.26 \pm 0.38$ & $2.07 \pm 0.27$ \\
\hline \multicolumn{6}{|l|}{ Stayman-like } \\
\hline (no crack) & 0 & 0 & $1.64 \pm 0.58$ & $\cdots$ & $1.64 \pm 0.58$ \\
\hline York & 24 & 32 & $2.64 \pm 0.30$ & $2.25 \pm 0.77$ & $2.60 \pm 0.28$ \\
\hline Jonathan & 68 & 80 & $1.79 \pm 2.05$ & $1.90 \pm 0.47$ & $1.88 \pm 0.43$ \\
\hline Winesap & 0 & 0 & $1.29 \pm 0.23$ & $\cdots$ & $1.29 \pm 0.23$ \\
\hline Starkrimson & 0 & 0 & $3.08 \pm 0.48$ & -.. & $3.08 \pm 0.48$ \\
\hline ia Gold & 0 & 0 & $2.51 \pm 0.21$ & $\cdots$ & $2.51 \pm 0.21$ \\
\hline Rome & $\mathbf{0}$ & 0 & $2.05 \pm 0.22$ & $\cdots$ & $2.05 \pm 0.22$ \\
\hline \multicolumn{6}{|l|}{ Golden Delicious } \\
\hline (Smoothee) & 12 & 40 & $3.10 \pm 0.43$ & $\ldots$ & $3.10 \pm 0.43$ \\
\hline
\end{tabular}

${ }^{\mathrm{z}}$ Means of 25 apples submerged for each cultivar.

${ }^{\mathrm{y}}$ Confidence limits, $P=0.05$, for noncracked, cracked, and all apples in each 25apple group.

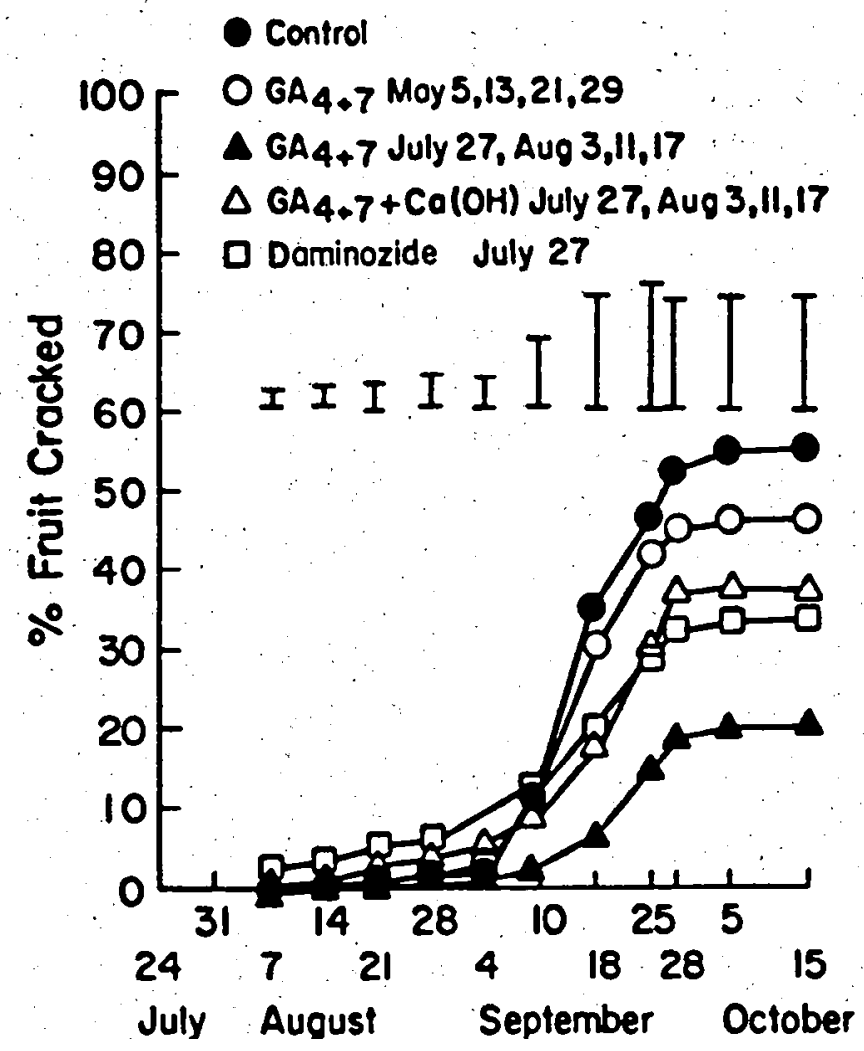

Fig. 1. Effect of four summer applications of $\mathrm{GA}_{4+7}$ at $20 \mathrm{mg} \cdot \mathrm{liter}^{-1}$ or one of daminozide at $1000 \mathrm{mg} \cdot \mathrm{liter}^{-1}$ on 'Stayman' fruit cracking. Vertical bars represent LSD $(\mathrm{P}<0.05)$. Each point represents a mean of six replicates, with a total of 150 to 300 apples per treatment (Expt. 7).

or peach wax did not alter the percentage weight gain when fruit were submerged in X-77 solution. The X-145A wax reduced water uptake when fruit were later submerged in X-77. Sucrose added to the X-77 did not reduce water uptake or cracking caused by X-77. Acetone, xylene, and chloroform increased water uptake when treated fruit were submerged in X-77, but only acetone increased cracking.
Experiment 5. 'Starkrimson Delicious' absorbed more water from an X-77 solution than 'Stayman', 'York', or 'Jonathan', but no 'Starkrimson' cracked (Table 6). In addition, a 'Stayman'-like apple, 'Virginia Gold', 'Rome', and 'Winesap' absorbed water but did not crack. These data suggest that certain cultivars can absorb water without cracking but others can not. Apple maturity may have some influence on fruit cracking in this test; however, 'Stayman' apples may be susceptible to cracking for 3 months before harvest, as well as during cold storage.

Experiment 6. In 1987, $\mathrm{GA}_{4+7}$ reduced fruit cracking from $58 \%$ to $21 \%$ if applied in four summer applications (Fig. 1). Spring applications did not reduce cracking. The addition of $\mathrm{Ca}(\mathrm{OH})_{2}$ to the $\mathrm{GA}_{4+7}$ spray applied in the summer did not reduce fruit cracking as much as $\mathrm{GA}_{4+7}$ alone. Daminozide reduced fruit cracking in 1987 but not as much as $\mathrm{GA}_{4+7}$. The spring applications of $\mathrm{GA}_{4+7}$ greatly reduced return bloom (data not presented), but the summer applications did not.

Experiment 7. Submerging 'Stayman' apples harvested 1417 Sept. 1987 from the $\mathrm{GA}_{4+7}$ summer spray treatment in Expt. 6 in $1.25 \mathrm{ml} \mathrm{X-77/liter} \mathrm{solutions} \mathrm{reduced} \mathrm{cracking;} \mathrm{however,}$ water uptake was not affected (Table 7). Daminozide-sprayed fruit that was submerged cracked and gained as much water as the control (X-77 surfactant solution.). On 6-8 Oct., both the $\mathrm{GA}_{4+7}$ and the daminozide field treatments reduced cracking, and daminozide reduced water uptake (Table 7). These data indicate that daminozide reduction of fruit cracking may be the result of reduced water uptake, but $\mathrm{GA}_{4+7}$ may be influencing cell wall strength or elasticity, but not water uptake.

Experiment 8. In 1988, spray application of daminozide (Fig. 2), Vapor Gard, NAA, RRW2, and superior spray oil (data not presented) did not reduce 'Stayman' fruit cracking; $\mathrm{GA}_{4+7}(10$ mg.liter ${ }^{-1}$ ) (Fig. 2) reduced fruit cracking by only $15 \%$, from $95 \%$ to $80 \%$. The addition of spray oil to $\mathrm{GA}_{4+7}$ at $2 \mathrm{mg} \cdot \mathrm{liter}^{-1}$ reduced cracking to a level similar to $10 \mathrm{mg} \mathrm{GA}_{4+7} /$ liter. Daminozide $+10 \mathrm{mg} \mathrm{\textrm {GA } _ { 4 + 7 }} /$ liter reduced fruit cracking by $20 \%$, from $95 \%$ to $75 \%$. When NAA $+\mathrm{GA}_{4+7}+$ Vapor Gard + daminozide were used in combination, fruit cracking was reduced by $73 \%$, from $95 \%$ to $27 \%$. The surfactant X-77 and an aluminum oxide formulation that contained a surfactant caused increased fruit cracking of $10 \%$ to $15 \%$ in the summer months, 
Table 7. Effect of submerging 'Stayman' apples 1 or 3 days in a surfactant solution $(0.125 \% \mathrm{X}-77)$ following $\mathrm{GA}_{4+7}$ or daminozide airblast spray treatments on fruit cracking and percentage weight gain in the laboratory $(1987$, Expt. 7$){ }^{\mathrm{Z}}$

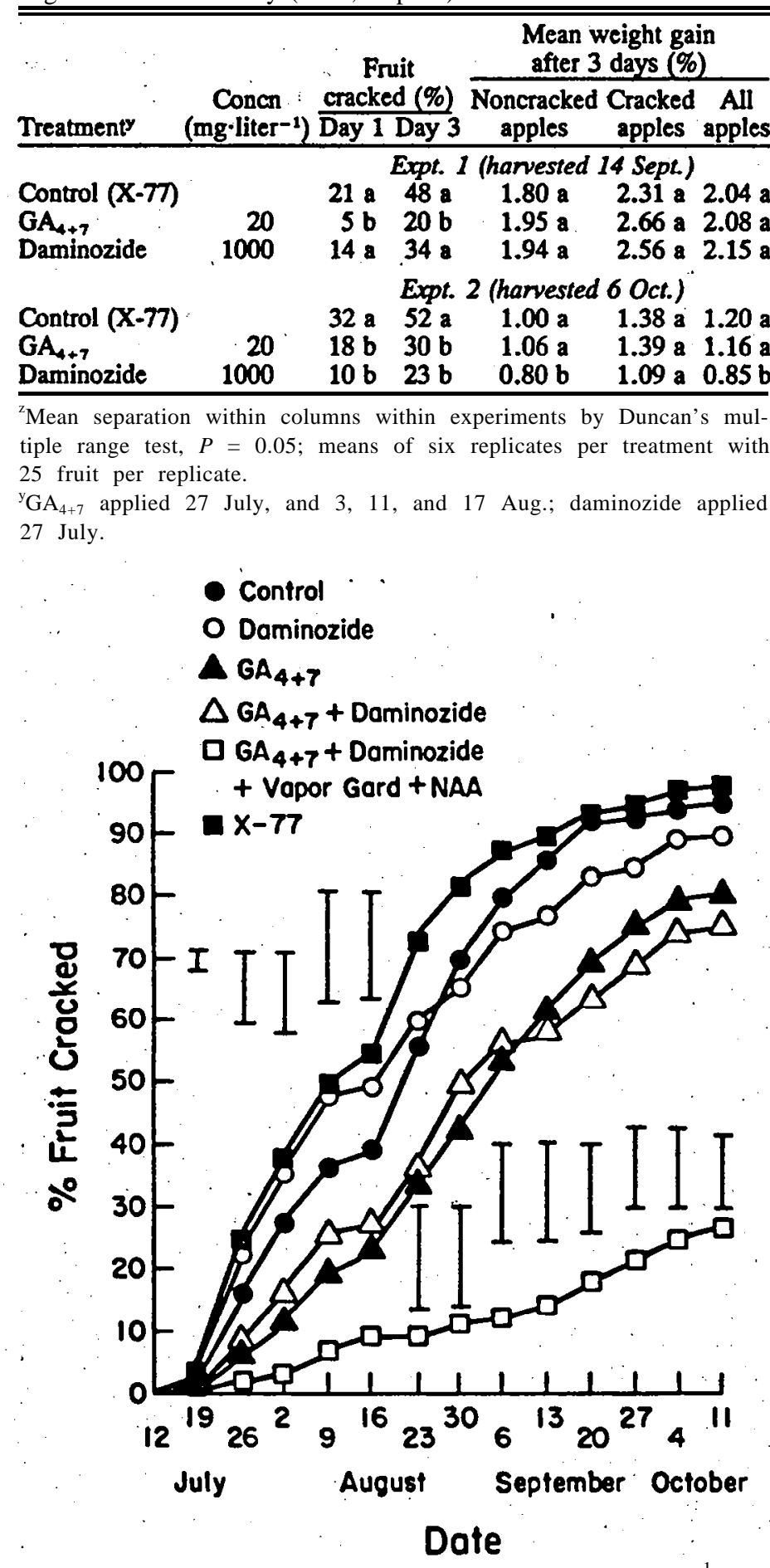

Fig. 2. Effect of five applications of $\mathrm{GA}_{4+7}$ at $10 \mathrm{mg} \cdot \mathrm{liter}^{-1}$, one application of daminozide at $1000 \mathrm{mg} \cdot \mathrm{liter}^{-1}$, or combination of these growth regulators on 'Stayman' fruit cracking. Data for treatments $3,4,7,9,12$, and 13 of Expt. 8 were not graphically presented. Vertical bars represent LSD $(P<0.05)$. Each point represents a mean of six replicates, with a total of 300 to 400 apples observed per treatment.

but this was not statistically significant. Fruit size was not affected by the treatments (data not presented). Treatments 4, 5,
6, 10, and 11 (see Materials and Methods) increased reddening of the fruit surface when compared to the control (treatments 5, 6, 10, and 11 all contained daminozide; data not presented). Neither the $\mathrm{GA}_{4+7}$ treatments nor any other treatment affected return bloom.

Experiment 9. Two scores around the trunk with a carpet knife reduced fruit cracking throughout the entire summer and fall (Fig: 3). If scoring had been done every 2 to 3 weeks, a greater effect on fruit cracking might have been realized. Root pruning only slightly reduced fruit cracking, from $93 \%$ to $86 \%$. Pruning, summer or dormant, did not significantly affect fruit cracking in the summer or fall. Neither fruit size, fruit color, nor return bloom were affected by the treatments (data not presented).

Experiment 10. Over-tree or under-tree sprinkling for one 12hr night period did not cause fruit cracking (Table 8). After 6 nights of sprinkling (9 Aug.), over-tree and under-tree sprinMing caused $9 \%$ and $7.6 \%$, respectively, of the fruit to crack. Some dew was deposited during this period, but exact records of duration and occurrence were not available. If significant periods of dew occurred during the night, then the under-tree sprinkled trees might have had free water on the leaves and fruit, and the cracking response might have been similar to overtree sprinkling. Fruit covered with bags or petroleum jelly on over-tree sprinkled trees did not crack, while $7.6 \%$ of the wetted fruit cracked. These data do not agree with those of Verner (1935), where fruit under a tarpaulin cracked. He found a small number of fruit cracked when a limb with 150 apples was covered with a tarpaulin.

Since the fresh market value of the 'Stayman' apple is frequently greater than that for 'Red Delicious', there is increasing

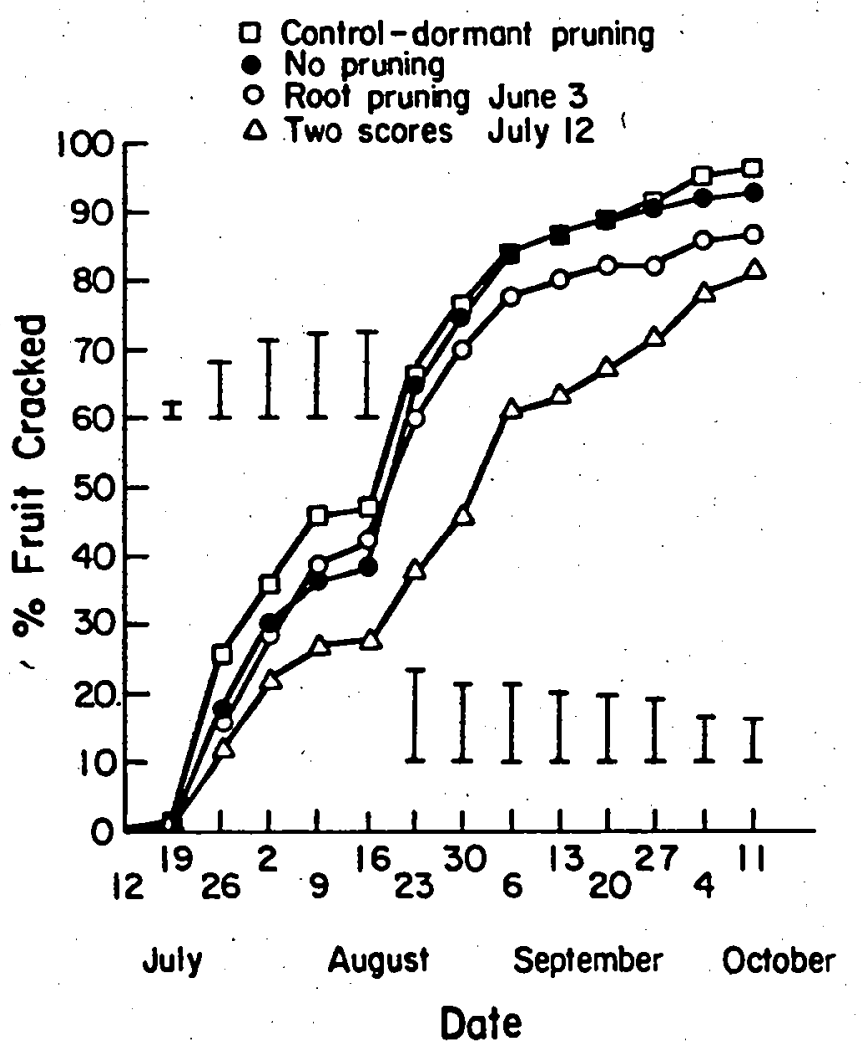

Fig. 3. Effect of scoring, root pruning, and dormant pruning on 'Stayman' fruit cracking. Vertical bars represent LSD $(\mathrm{P}<0.05)$. Each point represents a mean of nine replicates, with a total of 400 to 600 apples observed per treatment (Expt. 9). 
Table 8. Effect of overhead and under-tree watering on 'Stayman' apple fruit cracking (1988, Expt. 10).

\begin{tabular}{lcc}
\hline \hline & \multicolumn{2}{c}{ Fruit cracked $(\%)^{\mathrm{y}}$} \\
\cline { 2 - 3 } Treatment $^{\mathrm{z}}$ & 4 Aug. & 9 Aug. \\
\hline No watering & $0.0 \mathrm{a}$ & $0.9 \mathrm{a}$ \\
Under-tree sprinkling & $0.3 \mathrm{a}$ & $9.0 \mathrm{~b}$ \\
Overhead sprinkling & & \\
$\quad$ Nontreated & $0.0 \mathrm{a}$ & $7.6 \mathrm{~b}$ \\
Bagged fruit & $0.0 \mathrm{a}$ & $0.0 \mathrm{a}$ \\
Vaseline fruit & $0.0 \mathrm{a}$ & $0.0 \mathrm{a}$ \\
\hline
\end{tabular}

${ }^{\mathrm{z}}$ All trees were trickle-irrigated. Overhead- and under-tree-sprinkled trees were given $\approx 5 \mathrm{~cm}$ of water during $12 \mathrm{hr}$ for each of six nights, 3 to 9 Aug.

${ }^{\mathrm{y}}$ Mean separation within columns by Duncan's multiple range test, $P$ $=0.05$. Mean of 25 apples that were tagged on each of eight singletree replicates per treatment (400 apples per treatment observed on the trees on each date).

interest in a solution to the fruit cracking problem in the eastern United States. The data presented here suggest that submerging 'Stayman' apples in a nonionic (i.e., X-77) surfactant solution could be used to predict the potential for 'Stayman' fruit to crack under field conditions. In addition, four or five summer sprays of $\mathrm{GA}_{4+7}$ and its combination with daminozide, NAA, Vapor Gard, or scoring the tree trunk may lead to commercially acceptable reductions in fruit cracking.

\section{Literature Cited}

Adams, P.A., M.J. Montague, M. Tepfer, D.L. Rayle, H. Ikuma, and P.B. Kaufman. 1975. Effect of gibberellic acid on the plasticity and elasticity of Avena stem segments. Plant Physiol. 56:757-760.
Anderson, P.C. and D.G. Richardson. 1982. A rapid method to estimate fruit water status with special reference to rain cracking of sweet cherries. J. Amer. Soc. Hort. Sci. 107:441-444.

Batal, K.M., J.L. Weigle, and N.R. Lersten. 1972. Exogenous growthregulator effect on tomato fruit cracking and pericarp morphology. J. Amer. Soc. Hort. Sci. 97:529-531.

Bullock, R.M. 1952. A study of some inorganic compounds and growth promoting chemicals in relation to fruit cracking of 'Bing' cherries at maturity. Proc. Amer. Soc. Hort. Sci. 59:243-253.

Byers, R.E. 1987. Tree-row-volume spraying rate calculator for apples. HortScience 22:506-507.

Callan, N.W. 1986. Calcium hydroxide reduces splitting of 'Lambert' sweet cherry. J. Amer. Soc. Hort. Sci. 111:173-175.

Costa, G., C. Giulivo, and A. Ramina. 1983. Influence of growth regulators on apple fruit cracking (cv 'Stayman Red'). Acta Hort. 137:367-374.

Davenport, D.C., K. Uriu, and R.M. Hagan. 1972. Antitranspirant film: Curtailing intake of external water by cherry fruit to reduce cracking. HortScience 7:507-508.

Harrington, W.O., C.H. Hills, S.B. Jones, A.E. Stafford, and B.R. Tennes. 1978. Ethyloleate sprays to reduce cracking of sweet cherries. HortScience 13:279-280.

Marois, J.J., A.M. Bledsoe, R.M. Bostock, and W.D. Gubler. 1987. Effects of spray adjuvants on development of Botryris cinerea on Vitis vinifera berries. Phytopathology 77:1148-1152.

Sullivan, D.T. and F.B. Widmoyer. 1970. Effect of Alar on fruit cracking of Stayman winesap apple. Fruit Var. and Hort. Dig. 24: 1718.

Verner, L. 1935. A physiological study of cracking in 'Stayman' Winesap apples. J. Agr. Res. 51:191-222.

Westwood, M.N. and L.P. Batjcr. 1960. Effects of environment and chemical additives on absorption of naphthaleneacetic acid by apple leaves. Proc. Amer. Soc. Hort. Sci. 76:16-29.

Yoda, S. and J. Ashida. 1960. Effects of gibberellin and auxin on the extensibility of the pea steam. Plant \& Cell Physiol. 1:99-105. 